\title{
Teknologi Konstruksi: Sebuah Analisis
}

\author{
Arman Jayady ${ }^{1}$ \\ ${ }^{1}$ Staf Pengajar Jurusan Teknik Sipil \\ Program Studi Diploma IV Teknik Sipil \\ Politeknik Katolik Saint Paul Sorong \\ Email: ajayady@yahoo.co.id.
}

\begin{abstract}
Abstrak
Teknologi konstruksi adalah istilah yang sudah tidak asing saat ini, khususnya bagi akademisi dan praktisi di bidang konstruksi. Dalam penggunaanya sering terjadi overlapping dengan istilah-istilah lain yang mirip seperti teknologi rekayasa, teknologi desain, atau bahkan teknologi manufaktur. Studi ini bertujuan untuk menganalisis istilah teknologi konstruksi yang dimulai dari pemahaman teknologi sebagai subjek frase dan juga pemahaman konstruksi sebagai objek frase. Studi literatur, metode hermeneutika, serta proses sintesis digunakan dalam studi ini dalam menghasilkan konsep teknologi konstruksi yang jelas dan robust. Selain diperoleh konsep teknologi rekayasa yang jelas, hasil dari studi ini juga diperoleh kejelasan bahwa teknologi konstruksi terdiri atas tiga bagian penting yaitu teknologi proses konstruksi, teknologi produk konstruksi, dan teknologi manajemen konstruksi.
\end{abstract}

Kata kunci : Teknologi konstruksi, Teknologi proses konstruksi, Teknologi produk konstruksi, dan Teknologi manajemen konstruksi

\section{Pendahuluan}

Istilah teknologi konstruksi (tekon) sangat sering didengar dalam dunia konstruksi. Secara umum. Istilah tersebut biasanya dilekatkan dengan segala hal yang bersifat advanced, sophistecated, atau yang memiliki unsur kebaruan dalam dunia konstruksi yang mendukung efisiensi, kualitas, serta daya saing baik dari sisi produk maupun proses. Hal tersebut memberi beragam pengertian terkait tekon, sehingga dalam diskusidiskusi ilmiah sering terjadi overlapping pemahaman dengan istilah-istilah lain yang berdekatan, seperti: teknologi rekayasa (engineering technology), teknologi desain (design technology), atau bahkan teknologi manufaktur (manufacture technology) yang menghasilkan material konstruksi jadi atau setengah jadi (intermediate-product). Hal tersebut mendorong penulis untuk melakukan studi sehubungan konsep tekon. Studi ini bertujuan untuk menganalisis istilah tekon yang dimulai dari pemahaman teknologi sebagai subjek dari frase tekon dan juga pemahaman konstruksi sebagai objek dari frase tekon. Paper ini terdiri atas empat bagian utama yaitu, pertama adalah pendahulan yang menjelaskan urgensi serta tujuan utama dari penelitian ini. Bagian kedua adalah metode, yang menjelaskan tentang metode yang digunakan dalam penelitian ini. Selanjutnya, bagian ketiga adalah pembahasan konsep teknologi konstruksi. Terdapat tiga bagian utama yang dibahas pada bagian ketiga tersebut, yaitu pembahasan tentang konsep teknologi, konsep konstruksi, dan konsep teknologi konstruksi. Pada bagian ke empat atau bagian terakhir dari paper ini adalah berisi tentang diskusi dari penelitian ini yang diharapkan dapat menjadi acuan dalam penelitian-penelitian lanjutan.

\section{Metode}

Studi literatur digunakan dalam kajian ini dalam upaya mengeksplorasi konsep-konsep sebelumnya tentang tekon, baik pada masa klasik maupun mutakhir. Pendekatan eksploratif dapat digunakan dalam sebuah penelitian bila mana informasi atau pengetahuan sehubungan subjek riset yang akan diteliti tersebut masih sangat terbatas (Jayady, dkk., 2013; Jayady, 2017; Zulfiar dkk., 2018). Metode hermeneutika 
digunakan dalam analisis yang bertujuan untuk mencari makna implisit dari tiap definisi yang dikaji. Selain kedua metode tersebut, metode sintesis juga digunakan dalam mengelaborasi konsep sehingga menghasilkan konsep yang lengkap dari sisi ilmiah maupun praktis. Studi ini diharapkan dapat memberikan kejelasan sehubungan makna dari frase teknologi konstruksi.

\section{Pembahasan}

Penjelasan konsep teknologi konstruksi (tekon) secara lengkap tidak dapat diperoleh tanpa mengkaji dari setiap kata (elemen) dari frase tersebut. Sehingga pada bagian ini, kajian dibagi menjadi tiga bagian yaitu: konsep teknologi, konsep konstruksi, dan konsep teknologi konstruksi. Bagian pertama akan diuraikan berbagai definisi sehubungan kata teknologi, yang selanjutnya dengan metode hermeneutika akan ditarik makna yang terkandung (implisit) yang bersifat generik dan substansif dari berbagai definisi tersebut. Hal yang sama juga dilakukan pada konsep konstruksi yang merupakan objek frase. Sehingga pada bagian konsep teknologi konstruksi diharapakan diperoleh makna tekon yang jelas dan robust.

\subsection{Konsep Teknologi}

\subsubsection{Konsep Teknologi - Umum}

Istilah teknologi terdiri dari dua kata yang berasal dari bahasa Yunani (Greek) yaitu: techne dan logos. Aristoteles mengklasifikasi techne sebagai bagian dari knowledge yang bermakna know-how (OECD, 2000). Secara khusus Egmond (2012) memaknai techne sebagai know-how yang diperlukan untuk membuat sesuatu. Oleh Garud (1997) know-how adalah knowledge yang digunakan untuk merancang (design) atau memproduksi (manufacture) sesuatu. Know-how merepresentasikan generative processes (Garud, 1997). Sehingga know-how dapat diartikan sebagai knowledge yang bersifat aplikatifpraktis. Sedangkan logos dalam Bahasa Inggris dikenal sebagai logic bermakna prosedur yang bersifat logis (Halpin dan Senior, 2011). Secara lebih jelas logis dapat dimaknai sebagai sistematis. Sehingga teknologi secara generik dapat didefinisikan sebagai knowledge yang bersifat aplikatif-praktis serta sistematis yang berguna dalam memenuhi kebutuhan manusia.

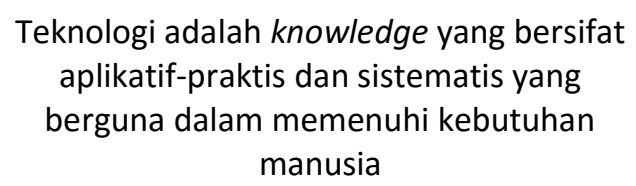

Teknologi adalah knowledge yang bersifat aplikatif-praktis dan sistematis yang berguna dalam memenuhi kebutuhan manusia

Box 1. Definisi teknologi secara umum

Grosse 1996 yang dikutip dari Osabutey dkk. (2014) membagi teknologi menjadi tiga bagian yaitu:

1. Teknologi Proses

2. Teknologi Produk

3. Teknologi Manajemen

Bagian berikut selanjutnya diuraikan sehubungan teknologi proses, teknologi produk, dan teknologi manajemen.

\subsubsection{Konsep Teknologi Proses}

Era tahun 1950-an istilah teknologi sering dikaitkan dengan industri manufaktur yang diartikan sebagai teknik-teknik yang digunakan dalam sistem atau proses produksi di pabrik (Orlikowski, 1992). Dalam perkembangannya pendefinisian terus dilakukan oleh para pakar sebagai upaya untuk memperoleh kejelasan dari makna dari teknologi tersebut. Paragraf berikut akan diuraikan beberapa definisi pakar sehubungan teknologi dalam konteks proses.

Menurut Jantsch 1967 (Jafarieh, 2001), teknologi adalah aplikasi yang memberi manfaat dari sains fisik, sains hayat, serta sains perilaku. Thompson 1967 (Jafarieh, 2001) menjelaskan bahwa teknologi adalah desain instrumental action untuk mereduksi ketidakpastian pada sebabakibat (outcome) dan harapan. Schon 1967 (Jafarieh, 2001) teknologi adalah metode kerja atau metode membuat oleh kemampuan manusia secara luas. Galbraith 1967 (Jafarieh, 2001) menjelaskan teknologi adalah aplikasi sistematis dari sains atau organized-knowledge untuk menjalankan tugas atau memecahkan masalahmasalah yang bersifat praktis. Menurut Peno and Wallender 1977 (Jafarieh, 2001) teknologi adalah knowledge yang melekat pada: produk, proses, formula, dan teknik yang diperlukan untuk mengelola operasi. Menurut Barquin 1981 (Jafarieh, 2001) teknologi adalah serangkaian dari disiplin-disiplin, metode-metode, teknikteknik, dan instrumen pendukung, yang digunakan dalam make-up proses dalam menghasilkan produk tangible terbaik. Dahlman 
1981 (Jafarieh, 2001) menjelaskan bahwa teknologi adalah kumpulan dari proses-proses fisik dalam mentransformasikan input menjadi output. Definisi yang bersifat makro juga disampaikan oleh Evans 1984 (Jafarieh, 2001) yang menjelaskan bahwa teknologi adalah upaya manusia untuk merubah atau mempengaruhi lingkungannya. Dosi 1984 (Jafarieh, 2001) mendefinisikan teknologi sebagai serangkaian segemen-segmen knowledge yang secara langsung mengandung praktek dan theoretical know-how, prosedur, pengalaman sukses, yang tidak hanya berwujud hardware tetapi juga dapat terdiri atas knowledge teknis dan skill dari partisipan dalam suatu organisasi. UNCTAD (2001) menjelaskan bahwa teknologi adalah knowledge sistematis yang digunakan untuk menghasilkan suatu produk, aplikasi sebuah proses, atau untuk menjalankan jasa (services), dan meliputi segala sesuatu yang terkait dengan manajerial dan teknik marketing. Jafarieh (2001) mendefinisikan teknologi sebagai segala cara yang digunakan untuk memenuhi kebutuhan dan hasrat manusia dengan menggunakan teknik yang sistematis. Secara lebih tegas, Halpin dan Senior (2011) memaknai techne sebagai metode atau teknik.

Berdasarkan uraian definisi di atas, nampak bahwa beberapa definisi merupakan perulangan dari definisi-definisi sebelumnya yang disampaikan dengan redaksi yang berbeda atau menggunakan kata yang berbeda namun berpadanan dengan kata pada definisi lainnya. Istilah atau frase yang dikemukakan oleh beberapa pakar di atas, seperti: aplikasi (Jantsch 1967 dikutip dari Jafarieh, 2001; OECD, 2000), instrumental action (Thompson 1967 dikutip dari Jafarieh 2001), metode kerja dan metode membuat (Schon 1967 dikutip dari Jafarieh 2001), aplikasi sistematis dan organizedknowledge (Galbraith 1967 dikutip dari Jafarieh 2001), teknik pengelolaan operasi (Peno and Wallender 1977 dikutip dari Jafarieh 2001), mentransformasikan (Dahlman and Westphal 1981 dikutip dari Jafarieh 2001), upaya manusia (Evans 1984 dikutip dari Jafarieh 2001), kesemuanya secara implisit bermakna knowhow, yang dalam konteks proses dapat diartikan sebagai metode atau teknik dalam menghasilkan produk atau mengoperasikan layanan (jasa). Sehingga substansi dari teknologi pada konteks proses adalah metode atau teknik.
Substansi teknologi pada konteks proses: Metode atau Teknik

Box 2. Substansi teknologi pada konteks proses

Sehingga teknologi dalam konteks proses atau teknologi proses dapat dikonsepkan sebagai:

Teknologi Proses: metode atau teknik dalam menghasilkan produk atau mengoperasikan layanan (jasa)

Box 3. Konsep teknologi proses

Metode atau teknik pada mulanya hanyalah sebuah explicit knowledge yang berwujud konsep, dan belum dapat memberi manfaat (value) pada suatu proses bila tidak didukung oleh komponen lain. Oleh Egmond (2012) komponen pendukung dari teknologi dalam konteks proses adalah: technoware (equipment, tools, dan machines), humanware (manpower), infoware (documented facts), orgaware (organizational framework). Gambar 1. berikut mendeskripsikan teknologi proses beserta keempat elemen pandukungnya.

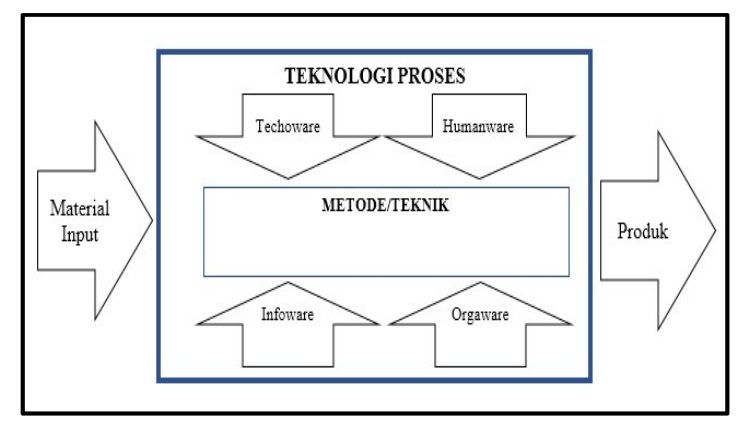

Gambar 1. Deskripsi teknologi proses beserta keempat elemen pandukungnya

\subsubsection{Konsep Teknologi Produk}

Menurut Egmond (2012), teknologi dalam perspektif sistem produksi selain sebagai teknologi dalam konteks proses atau teknologi proses, juga terwujud dalam teknologi dalam konteks produk atau teknologi produk. Teknologi produk adalah knowledge dan skill yang melekat pada keluaran proses produksi yang diperlukan (bermanfaat) bagi pengguna (Egmond, 2012). Egmond (2012) mendeskripsikan knowledge serta skill yang melekat pada produk (bangunan) seperti pada Gambar 2. 


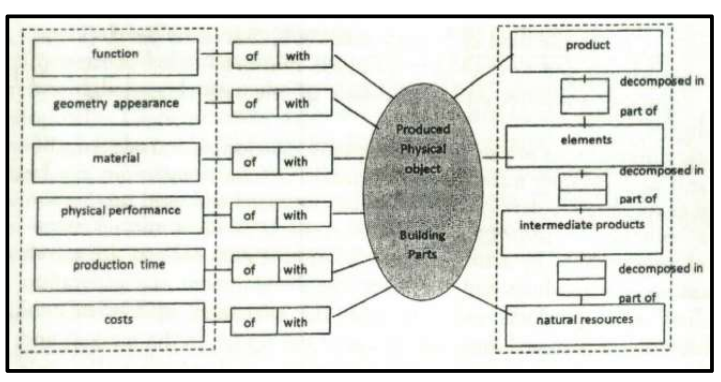

Gambar 2. Deskripsi teknologi produk

(sumber: Egmond, 2012)

Berdasarkan deskripsi knowledge serta skill yang melekat pada produk seperti pada Gambar 2, knowledge atau skill tersebut bukanlah lagi sebagai know-how (substansi teknologi), namun oleh Garud (1997) disebut sebagai knowledge know-what, yaitu knowledge tentang konfigurasi suatu sistem. Namun, knowledge dan skill (knowhow) yang melekat pada suatu produk pada hakekatnya telah terwujud dalam karakteristik serta fitur bernilai pada produk tersebut. Sehingga substansi pada teknologi produk adalah karakteristik dan fitur bernilai yang melekat pada suatu produk. Dengan demikian teknologi pada konteks produk atau teknologi produk dapat diartikan sebagai karakteristik dan keseluruhan fitur bernilai pada suatu produk (termasuk elemen penyusun) yang dapat memberi manfaat lebih bagi pengguna produk tersebut.

Substansi teknologi produk:

karakteristik dan fitur bernilai yang melekat pada suatu produk

Box 4. Substansi teknologi produk

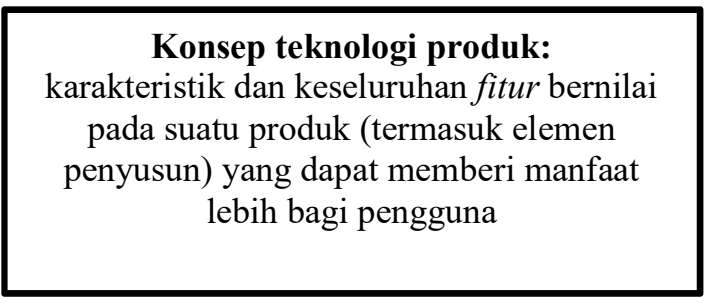

Box 5. Konsep teknologi produk

\subsubsection{Konsep Teknologi Manajemen}

Menurut Grosse 1996 yang dikutip dari Osabutey dkk. (2014) teknologi manajemen didefinisikan sebagai knowledge atau keberadaan skill manajerial dalam pengelolaan sumber daya secara efektif yang digunakan dalam operasi bisnis pada suatu perusahaan dalam berkompetisi. Meski Gross menggunakan istilah knowledge atau skill manajerial, namun secara implisit knowledge atau skill manajerial yang dimaksud bukanlah know-why (episteme), tetapi know-how (techne) yang umumnya dikenal sebagai metode atau teknik. Seperti halnya pada teknologi proses. Pada teknologi manajemen juga melibatkan empat komponen utama pendukung yaitu: technoware (equipment, tools, dan machines), humanware (manpower), infoware (documented facts), orgaware (organizational framework). Sehingga teknologi manajemen dapat dikonsepkan sebagai metode atau teknik dalam pengelolaan sumber daya secara efektif yang digunakan dalam operasi bisnis pada suatu perusahaan dalam berkompetisi.

\section{Konsep teknologi manajemen:} metode atau teknik dalam pengelolaan sumber daya secara efektif yang digunakan dalam operasi bisnis pada suatu perusahaan dalam berkompetisi, yang mana metode dan teknik tersebut didukung oleh empat komponen utama, yaitu: technoware (equipment, tools, dan machines), humanware (manpower), infoware (documented facts), orgaware (organizational framework)

Box 6. Konsep teknologi manajemen

Gambar 3 di bawah ini adalah deskripsi dari teknologi manajemen. Proses bisnis seperti yang dimaksudkan pada Gambar 3 adalah juga meliputi teknologi proses.

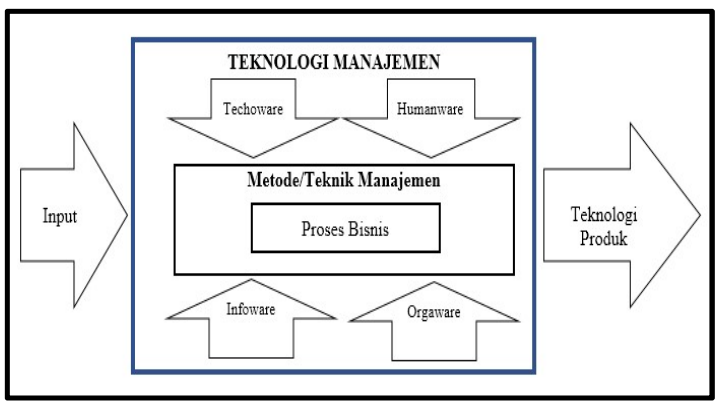

Gambar 3. Deskripsi teknologi manajemen 


\subsection{Konsep Konstruksi}

Secara umum konstruksi dapat diinterpretasi dalam empat level, yaitu: sebagai aktivitas di lapangan (level satu), sebagai konperehensif siklus proyek (level dua), sebagai segala hal yang berhubungan dengan bisnis konstruksi (level tiga), dan sebagai proses secara luas dalam mengkreasi hunian manusia (level empat) (Du Plessis, 2007).

Berdasarkan keempat interpretasi di atas, maka dalam pendefinisian segala sesuatu yang berhubungan dengan konstruksi, baik dalam diskusi ilmiah maupun paper ilmiah sering terjadi multi-tafsir. Dalam konteks studi ini, konstruksi sebagai frase dari teknologi konstruksi adalah penting dilakukan pembatasan, karena konstruksi dalam frase tekon juga berfungsi sebagai delimitasi cakupan teknologi itu sendiri.

Menurut Du Plessis (2007), secara umum konstruksi dimaknai sebagai aktivitas di lapangan dalam merealisasikan bangunan. Halpin dan Senior (2011) dalam menjelaskan tekon, juga mendelimitasi konstruksi sebagai aktifitas di lapangan dalam merealisasikan pekerjaan fisik. Demikian juga halnya dengan Egmond (1999) melalui ilustrasinya sehubungan teknologi proses (lihat Gambar 4) menunjukkan bahwa konstruksi yang dimaksud Egmond (1999) adalah aktfitas di lapangan (aktifitas proses dari teknologi). Hal tersebut ditunjukkan dengan adanya raw material dan produk setengah jadi (intermediate) sebagai bahan input pada ilustrasi Egmond (1999) (lihat Gambar 4). Sehingga konstruksi yang dimaksud dalam studi ini adalah aktfitas di lapangan dalam merealisasikan secara fisik bangunan yang didesain sebelumnya.

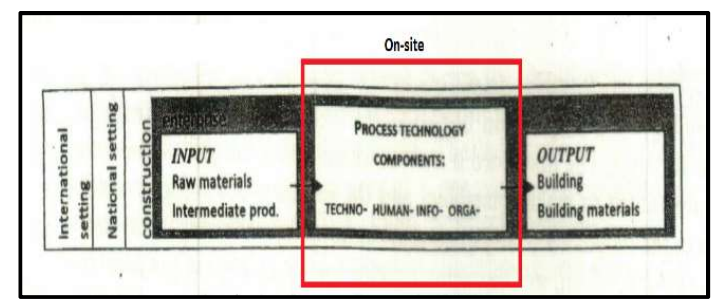

Gambar 4. Deskripsi konstruksi menurut Egmond (2012)
Konsep konstruksi:

Aktifitas di lapangan dalam merealisasikan secara fisik dari bangunan yang didesain sebelumnya

Box 7. Konsep konstruksi

Penjelasan tersebut di atas juga menunjukkan bahwa terjadi pemisahan makna antara teknologi konstruksi dan teknologi desain nantinya.

\subsection{Konsep Teknologi Konstruksi}

Bila mengacu pada Egmond (1999), maka teknologi konstruksi terdiri atas: teknologi proses konstruksi dan teknologi produk konstruksi. Namun, bila berdasarkan uraian konsep teknologi (3.1) dan konsep konstruksi (3.2) seperti yang diuraikan sebelumnya maka, teknologi konstruksi terdiri atas:

1. Teknologi proses konstruksi

2. Teknologi produk konstruksi

3. Teknologi manajemen konstruksi

Teknologi konstruksi terdiri atas tiga bagian utama yaitu: teknologi proses konstruksi, teknologi produk konstruksi, dan teknologi manajemen konstruksi

Box 8. Pembagian teknologi konstruksi (tekon)

\subsubsection{Konsep Teknologi Proses Konstruksi}

Bila mengacu pada uraian konsep teknologi proses (3.1.2) dan uraian konsep konstruksi (3.2), maka konsep teknologi proses konstruksi dapat diformulasikan seperti ditunjukkan pada Box 9 berikut:

Konsep Teknologi proses konstruksi adalah: metode atau teknik yang dilakukan di lapangan dalam merealisasikan produk teknologi konstruksi, yang mana metode atau teknik tersebut didukung oleh empat komponen utama yaitu: technoware (equipment, tools, dan machines), humanware (manpower), infoware (documented facts), orgaware (organizational framework)

Box 9. Konsep teknologi proses konstruksi 
Gambar 5 berikut merupakan deskripsi dari konsep teknologi proses konstruksi.

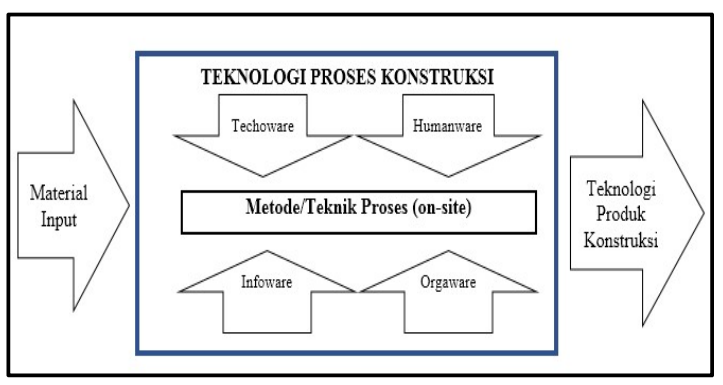

Gambar 5. Deskripsi teknologi proses konstruksi

\subsubsection{Konsep Teknologi Produk Konstruksi}

Bila mengacu pada uraian konsep teknologi produk (3.1.3) dan uraian konsep konstruksi (3.2), maka konsep teknologi produk konstruksi dapat diformulasikan seperti ditunjukkan pada Box 10 berikut:

\section{Konsep Teknologi produk konstruksi adalah: karakteristik dan keseluruhan fitur bernilai pada suatu produk konstruksi (termasuk elemen penyusun) yang dapat memberi manfaat lebih bagi pengguna}

Box 10. Konsep teknologi produk konstruksi

Hubungan teknologi proses konstruksi dan teknologi produk konstruksi dapat diilustrasikan seperti pada Gambar 6 di bawah ini.

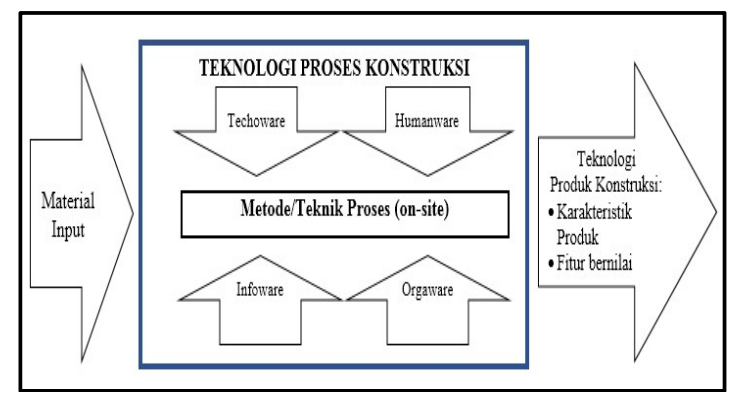

Gambar 6. Deskripsi hubungan teknologi proses konstruksi dan teknologi produk konstruksi

\subsubsection{Konsep Teknologi Manajemen Konstruksi}

Dalam memformulasikan konsep teknologi manajemen konstruksi, maka konsep konstruksi tidak terbatas hanya pada aktifitas lapangan, seperti yang dimaksud Du Plessis (2007) sebagai interpretasi level satu pada konsruksi. Namun dalam konteks ini, dapat digunakan interpretasi level tiga dari konstruksi yaitu segala hal yang berhubungan dengan bisnis konstruksi. Hal tersebut dikarenakan dalam menjalankan operasi bisnis konstruksi, manajer (eksekutif) terhubung dengan stakeholder secara luas yang terkait dengan bisnis konstruksi.

Sehingga, bila mengacu pada uraian konsep teknologi manajemen (3.1.4) dan pemahaman konstruksi pada level tiga menurut Du Plessis (2007), maka konsep teknologi manajemen konstruksi dapat diformulasikan seperti pada Box 11 berikut:

Konsep teknologi manajemen konstruksi: metode atau teknik dalam pengelolaan sumber daya secara efektif yang digunakan dalam operasi bisnis konstruksi pada suatu perusahaan dalam berkompetisi, yang mana metode dan teknik tersebut didukung oleh empat komponen utama, yaitu: technoware (equipment, tools, dan machines), humanware (manpower), infoware (documented facts), orgaware (organizational framework)

Box 11. Konsep teknologi manajemen konstruksi

Gambar 7 di bawah ini adalah deskripsi dari teknologi manajemen konstruksi. Proses bisnis konstruksi seperti yang dimaksudkan pada Gambar 7 adalah juga meliputi teknologi proses konstruksi.

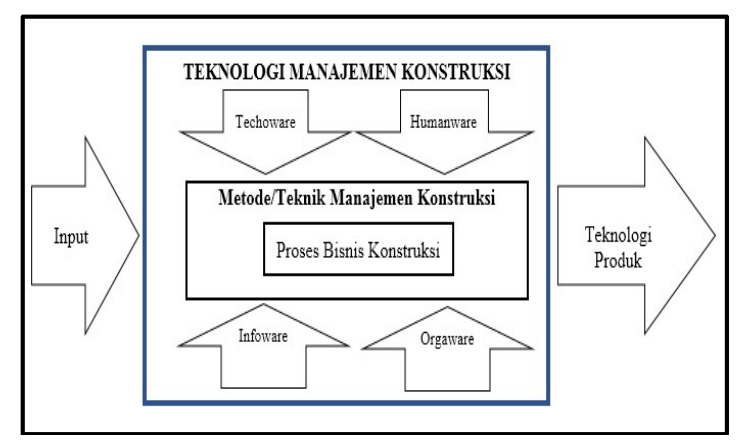

Gambar 7. Deskripsi teknologi manajemen konstruksi

\section{Kesimpulan}

Teknologi konstruksi terdiri atas tiga bagian, yaitu: teknologi proses konstruksi, teknologi produk konstruksi, dan teknologi manajemen 
konstruksi. Kata konstruksi yang melekat pada frase teknologi proses konstruksi, bermakna aktifitas di lapangan dalam merealisasikan fisik bangunan, yang juga sekaligus mendelimitasi cakupan teknologi yang digunakan, sehinga konsep teknologi proses konstruksi pada studi ini adalah: metode atau teknik yang dilakukan di lapangan dalam merealisasikan produk teknologi konstruksi, yang mana metode atau teknik tersebut didukung oleh empat komponen utama yaitu: technoware (equipment, tools, dan machines), humanware (manpower), infoware (documented facts), orgaware (organizational framework).

Hasil analisis pada studi ini juga diperoleh kejelasan bahwa konsep teknologi produk konstruksi adalah: karakteristik dan keseluruhan fitur bernilai pada suatu produk konstruksi (termasuk elemen penyusun) yang dapat memberi manfaat lebih bagi pengguna. Sehingga setiap bangunan yang memiliki karakteristik dan fitur yang bernilai bagi pengguna (output teknologi proses konstruksi) disebut juga sebagai teknologi produk konstruksi. Pemahaman ini juga meliputi komponen penyusun bangunan yang memiliki ciri karakteristik dan fitur yang bernilai.

Pada studi ini juga diperoleh kejelasan bahwa konsep teknologi manajemen konstruksi adalah metode atau teknik dalam pengelolaan sumber daya secara efektif yang digunakan dalam operasi bisnis konstruksi pada suatu perusahaan dalam berkompetisi. Metode dan teknik yang dimaksud adalah terdiri dari empat komponen utama, yaitu: technoware (equipment, tools, dan machines), humanware (manpower), infoware (documented facts), orgaware (organizational framework). Kata konstruksi untuk frase teknologi manajemen konstruksi bermakna segala hal yang berhubungan dengan konstruksi. Hal tersebut dikarenakan, dalam menjalankan operasi bisnis konstruksi, manajer (eksekutif) terhubung dengan stakeholder secara luas yang terkait dengan bisnis konstruksi.

\section{Daftar Pustaka :}

Du Plessis, C. (2007): A Stratetegic framework for sustainable construction in developing countries, construction management and economic journal, 25, p. 67-76.

Egmond, E.V. (2012): Construction technology development and innovation, p.185-228, dalam Ofori G., ed., new perspective on construction in developing countries, 388 hal., Spon Press, London \& New York.

Garud, R. (1997): On the distinction know why know how - and know why, Advances Strategic Management, JAI Press., 14, 81 101.

Halpin, D. W., dan Senior, B. A. (2011): Construction management, John Wiley \& Sons, Inc., New Jersey, p.13 - 16.

Jafarieh, H. (2001): Technology transfer to developing countries: a qualitative approach, Doctoral Dissertation, Univerisity of Salford Iran, p. 11-13.

Jayady, A. (2017). "Joint Operation dalam Studi Kualitatif”, Jurnal Karkasa, Vol. 3.1, Politeknik Katolik Saint Paul Sorong, Indonesia.

Jayady, A., Pribadi, K.S., Abduh, M., \& Bahagia, S.N. (2017). "Model Penilaian Keberhasilan Transfer of Knowledge pada Joint Operation antara Perusahaan Jasa Konstruksi Asing dan Perusahaan Jasa Konstruksi Lokal", Disertasi Doktor, Fakultas Teknik Sipil dan Lingkungan, Institut Teknologi Bandung (ITB), Bandung, Indonesia.

Jayady, A., Pribadi, K.S., Abduh, M., \& Bahagia, S.N. (2013). "Perkembangan Joint Operation di Indonesia", Prosiding : Seminar Nasional Teknik Sipil IX, Institut Teknologi Sepuluh November - Surabaya, 9 February 2013

Jayady, A., Pribadi, K.S., Abduh, M., \& Bahagia, S.N. (2013). "A Study of Joint Operation Scheme in Indonesia", Prosiding : The 6TH Civil Engineering Confrence in The Asian Region, 20-22 Agustus 2013.

OECD. (2000): Knowledge management in the learning society-education and skill, OECD publications service, france,

Orlikowski, W. J. (1992): The duality of technlogy: rethingking of technology in organizations, Organization Science, 3(3), $398-427$.

Osabutey, E. L. C., Williams, K. dan Debrah, A. Y. (2014): The potential for technology and knowledge transfers between foreign and local Firms: A study of the construction industry in Ghana, Journal of World Business. 49(4), 560-571.

UNCTAD (2001): Transfer of technology, United Nation Conference on Trade and Development, UN, New York and Geneva, p.4-6. 


\section{Jurnal Karkasa}

Vol.4, No.1, 2018, ISSN: 2580-7595

Zulfiar, M.H., Jayady, A., dan Saputra, N.R.J. (2018). "Kerentanan Bangunan Rumah Cagar Budaya Terhadap Gempa di Yogyakarta", Jurnal Karkasa, Vol. 4.1, Politeknik Katolik Saint Paul Sorong, Indonesia.

Penelitian ini didukung oleh divisi penelitian dan pengembangan (Litbang) Lembaga Pengembangan Jasa Konstruksi Nasional (LPJKN) beserta tim ahli dari Institut Teknologi Bandung (ITB) 